Article

\title{
Pattern and Influencing Factors of Foreign Direct Investment Networks between Countries along the "Belt and Road" Regions
}

\author{
Quan $\mathrm{He}^{*}$ (D) and Xishen Cao \\ School of Economics and Management, China University of Geosciences, Beijing 100083, China \\ * Correspondence: heq13@cugb.edu.cn
}

Received: 6 July 2019; Accepted: 22 August 2019; Published: 29 August 2019

\begin{abstract}
With the in-depth implementation of the "Belt and Road" initiative (BRI), the investment patterns between Belt and Road countries have also become more complicated. The impact of this complex investment network on regional economic development is also growing. To reveal the complexity of this investment pattern, and to better promote the sustainable development of the region's economy, this paper used the complex network method to study the foreign direct investment (FDI) network of 50 countries along the Belt and Road from 2003 to 2017, revealing its structural and behavioral characteristics and evolution process. The results showed that the imbalance of the investment network structure is outstanding, and preferential selection behavior is obvious. The Central and Eastern European countries show significant clustering behavior. In addition, the network evolved slowly and followed the "Pareto rule" in the early stages of its evolution. The BRI was a turning point in the evolution process. On this basis, the quadratic assignment procedure (QAP) regression analysis method was used to further study the factors affecting the formation process of this investment pattern. It found that economic development level, geographical distance, and bilateral trade were the main influencing factors. Among them, bilateral trade had the greatest impact on the pattern of network.
\end{abstract}

Keywords: "belt and road" Initiative; regional investment; FDI network pattern; complex network; influencing factors; QAP

\section{Introduction}

As an international cooperation platform dedicated to promoting economic integration and development, the "Belt and Road" initiative (short for "New Silk Road" and "21st Century Maritime Silk Road") is currently attracting the attention of governments and scholars [1-4]. It connects Asia, Europe, and Africa. These regions are home to more than 60 countries and have a world population of $60 \%$, accounting for $30 \%$ of the world's total GDP [5]. Therefore, the practice of the Belt and Road initiative will greatly promote the economic integration process and sustainable development of these three major regions. Foreign direct investment is an important part of regional economic cooperation, which has profoundly affected the process of regional economic development and integration. Hence, foreign direct investment cooperation has been included in the key content of the "Belt and Road" initiative. As the initiative is recognized and supported by more and more countries, the willingness to cooperate in foreign direct investment between countries of the three regions is also growing. This will not only facilitate the acceleration of inter-regional foreign direct investment, but also contribute to the development of regional economies in Asia, Europe, and Africa and the achievement of sustainable development goals. 
Therefore, how to effectively promote and realize foreign direct investment cooperation among countries along the Belt and Road region is worthy of consideration by scholars and policy makers. This paper argues that to solve this problem, we first need to see that the Belt and Road initiative involves Asia, Europe, and Africa, including more than 60 countries, which undoubtedly highlights the complexity of Belt and Road foreign direct investment. Moreover, due to the in-depth practice of the "Belt and Road" initiative, foreign direct investment (FDI) in this area is becoming more and more complex. Therefore, before answering this question, scholars and policymakers need to effectively study the complexity of FDI in this region, and analyze the FDI patterns of the whole region and the evolution trends of FDI in the future. More importantly, they need to identify the key factors that influence the development of this pattern. By analyzing the conclusions obtained, we can scientifically leverage the Belt and Road initiative investment cooperation platform to effectively promote regional economic development and achieve regional sustainable development goals. In addition, analysis and research can help to identify the investment patterns and logic of enterprises down the line.

Thus, it is undoubtedly necessary and urgent to study the pattern of foreign direct investment in the area along the Belt and Road. However, many existing studies have ignored the importance of this issue, most of which have focused on the investment pattern of China or a country in that region [6-9]. Although these conclusions reveal to some extent the investment structure of some countries in the Belt and Road region, they display a lack of systematicity and comprehensiveness.

Based on this, from the perspective of complex networks, this paper established foreign direct investment network models of countries along the line, and systematically studied the characteristics and evolution of foreign direct investment networks along the Belt and Road region by analyzing the relevant measurement indicators of the model. In addition, this paper further used the quadratic assignment procedure (QAP) regression analysis method to explore the main influencing factors of the formation of the foreign direct investment network in the Belt and Road region. Overall, the conclusions of this paper revealed the pattern and evolution of foreign direct investment along the Belt and Road region, and explain the main reasons for the formation of this investment pattern.

The contributions of this paper mainly include the following three points: (1) this paper overcame the shortcomings of the methods used in previous studies to study regional investment. From the perspective of complex systems, using the method of the complex network, this paper studied the investment pattern along the Belt and Road area, and expanded the application of the complex network method in the research area of regional investment. (2) Based on the regional investment pattern along the Belt and Road, this paper further studied the main factors affecting the formation of this pattern using the QAP regression analysis method, which brought new insights and findings relevant to regional investment research. (3) The paper also identified the location determinants of foreign direct investment in countries along the Belt and Road regions, and has provided effective policy recommendations on how to promote regional investment cooperation along the Belt and Road and promote regional economic integration and sustainable development.

The basic conclusion of this paper was that the foreign direct investment network along the Belt and Road region has obvious structural and behavioral characteristics. The year the Belt and Road initiative was proposed, 2013, was an important turning point in the evolution of the investment network pattern between Asia, Central and Eastern Europe, and North Africa. Additionally, factors including economic development level, bilateral trade, and geographical distance have influenced and contributed to the formation of regional investment network patterns along the Belt and Road route. At the same time, these factors have also been the decisive factors in the location choice of direct investment among countries along the "Belt and Road"areas. Bilateral foreign direct investment between countries in this region is typically "trade-driven" and "market-seeking".

The rest of the paper is organized as follows: Section 2 reviews the literature. Section 3 introduces the data and methods. Section 4 illustrates measurement indicators of complex network models. Section 5 analyzes the patterns and evolution process of the investment network. Section 6 uses the QAP multiple regression analysis method to further study the influencing factors of the network 
pattern. Section 7 presents the discussion. Conclusions and policy recommendations are presented in Section 8.

\section{Literature Review}

At present, there have been many studies on the investment theme of the Belt and Road initiative, and the results have been rich [6-13]. For example, Kang et al. used difference in difference (DID) and propensity score matching (PSM) methods to test the impact of the Belt and Road initiative on the outward foreign direct investment (OFDI) of China. The results showed that the "Belt and Road" initiative has had a positive impact on China's foreign direct investment, but that this is mainly reflected in institutional cooperation and cultural integration. In addition, the authors also found that the determinants of the OFDI of China have changed since the Belt and Road initiative. Additionally, the motivation of natural resource seeking was significantly weakened in the location selection of the OFDI, while the motivation of market-seeking was significantly enhanced [10]. Zheng and Liu studied the spatial patterns of the OFDI of China along the Belt and Road regions, and found that Chinese FDI along these regions had a large difference in distribution, and the investment industry was relatively focused. The FDI of China is mainly concentrated in Southeast Asia, while it has less investment in Central and Eastern Europe and South Asia [6].

Liu et al. used Probit and feasible generalized least squares (FGLS) methods to study the agglomeration effects and determinants of Chinese FDI under the Belt and Road initiative [12]. Fan et al. studied the direct investment efficiency of China along the Belt and Road region through a stochastic frontal gravitational model and frontier regression model. It was found that investment efficiency of China in the region was high and showed an upward trend [13].

Based on these references, it was found that existing research has mainly focused on investment issues of China and the Belt and Road regional countries, such as Chinese investment patterns, Chinese investment efficiency, and investment determinants.

However, they have ignored the complex bilateral investment relationships between other countries along the Belt and Road areas. Moreover, it is difficult to assess the investment status of the entire regions along the Belt and Road. At the same time, existing studies also have not put forward effective recommendations for the sustainable development of regional investment along the Belt and Road. In addition, most studies have used the relevant methods of econometrics in their Belt and Road investment research. However, to some extent, these methods limit scholars from studying the overall investment situation along the Belt and Road region systematically. Additionally, what factors affect bilateral investment between countries along the Belt and Road regions? How do these factors affect bilateral investment behavior among regional countries? The existing literature has also not effectively studied and explored these issues.

Therefore, this paper broke from the limitation of econometric methods, using the complex network method from the field of economic physics, from the perspective of complex systems, to study the pattern of the investment network between countries along the Belt and Road areas. This has made up for the shortcomings of the existing research on Belt and Road regional investment. Furthermore, we have discussed which factors impact investment patterns along the Belt and Road regions, and how. This paper makes up for the research gaps on the influencing factors of the pattern of the investment network along the Belt and Road region, and provides policy recommendations for the sustainable development of investment in the Belt and Road regions.

\section{Methodology and Data}

\subsection{Complex Network Methods}

Complex network is an effective method by which to understand the essence of real economic systems [14-21]. The main idea is to consider the relationships among various parts of real complex systems as a complex network. Any network can be seen as being composed of nodes and edges 
connected together. By constructing a complex network model of the system, and analyzing all the nodes and edges in the network, the basic features of the real complex system can be better understood [22]. A complex network model can be abstracted into a graph $G=(V, E)$ consisting of a set of points, $\mathrm{V}$, and a set of edges, $\mathrm{E}$. The number of nodes is $\mathrm{N}=\mathrm{V}$, and the number of edges is $\mathrm{M}=\mathrm{E}$. Each edge in $\mathrm{E}$ has a pair of points corresponding to $\mathrm{V}$. When the edge in graph $\mathrm{G}$ has a specific direction, it is called a directed network. If each edge in graph $\mathrm{G}$ is given a corresponding weight value $\mathrm{W}$, it is called a directed weight complex network. Otherwise it is called an undirected and unweighted network [23].

\subsection{Construction of Belt and Road Countries' FDI Networks}

Based on the above methods, this paper chose to construct directed and weighted complex network models. Fifty countries were regarded as nodes, and the investment relationships between countries were edges. Investment flows between these countries were the weights of edges. By arranging the data, the adjacency matrix $A=\left[a_{i j}\right](i=1,2, \ldots n, j=1,2, \ldots n)$ of nodes and adjacency matrix $W=\left[w_{i j}\right]$ ( $i=1,2, \ldots n, j=1,2$,) of weights were established, as shown in Equations (1) and (2). If the $j$-th country introduced the foreign direct investment of the $i$-th country in year $t$, then $a_{i j}(t)=1, w_{i j}(t)=$ the flow of direct investment from country $i$ to country $j$. If the $j$-th country did not introduce foreign direct investment from the $i$-th country in the year $t$, then adjacency matrices $a_{i j}(t)=0, w_{i j}(t)=0$.

$$
\begin{gathered}
A=\left[a_{i j}(t)\right]=\left[\begin{array}{ccc}
a_{11} & \cdots & a_{1 j} \\
\vdots & \ddots & \vdots \\
a_{i 1} & \cdots & a_{i j}
\end{array}\right] \\
W=\left[w_{i j}(t)\right]=\left[\begin{array}{ccc}
w_{11} & \cdots & w_{1 j} \\
\vdots & \ddots & \vdots \\
w_{i 1} & \cdots & w_{i j}
\end{array}\right]
\end{gathered}
$$

\subsection{Measurement Indicators of FDI Networks}

\subsubsection{Network Density}

Network density is used to measure the tightness of the connection between all nodes in a network. It is the ratio of the total number of connected edges $m$ actually existing in the network to the total number of nodes $n$ connected in theory. In general, a higher network density indicates that the tightness of the connection between network nodes is stronger. In the Belt and Road foreign direct investment networks, a higher density indicates that there are many inter-connected relationships among countries in the network, and the investment links between countries are very close. The definition of network density is given by Equation (3):

$$
D=\frac{m}{n(n-1)}
$$

where $m$ is the number of actual relationships in a network and $n$ is the number of the network.

\subsubsection{Clustering Coefficient}

The clustering coefficient is an important index used to measure the degree of grouping between nodes in the network. The larger the node clustering coefficient is, the closer the relationship between a node and its neighbors is. When the average clustering coefficient of the network nodes is higher, it indicates that the degree of grouping of the network pattern is higher, and the differentiation phenomenon is obvious. It is defined by Equation (4) [24-26]: 


$$
C_{i}^{w}=\frac{\sum_{j \neq i} \sum_{h \neq(i, j)} w_{i j}^{\frac{1}{3}} w_{i h}^{\frac{1}{3}} w_{j h}^{\frac{1}{3}}}{k_{i}\left(k_{i}-1\right)}
$$

where $j$ and $h$ represent other nodes in the network that can form a triangle with node $i ; k_{i}$ is the degree of the node $i, w_{i j}$ is the weight of the edge from node $i$ to node $j ; w_{i h}$ is the weight of the edge from node $i$ to node $j$; and $w_{j h}$ is the weight of the edge from node $j$ to node $h$.

\subsubsection{Node Degree and Degree Distribution}

The degree of node $i$ in the network refers to the number of nodes that have a connection with node $i$. In a directed complex network, the degree of a node is divided into out-degree and in-degree. The out-degree of node $i$ is the total number of edges from the node $i$ to other nodes. The in-degree of the node $i$ is the number of edges of other nodes pointing to node $i$. The greater the degree of a node is, the greater the importance in the network is. These terms are defined by Equations (5) and (6) [27]. In the Belt and Road FDI network, the in-degree of node $i$ indicates how many countries made direct investments in country $i$. The out-degree of node $i$ indicates that how many countries were invested in by country $i$.

$$
\begin{gathered}
K_{i}^{\text {out }}=\sum_{j=1}^{n} a_{i j} \\
K_{i}^{i n}=\sum_{j=1}^{n} a_{j i}
\end{gathered}
$$

where $n$ is the total number of nodes in the network, and $a_{i j}, a_{j i}$ are the values of the corresponding elements in the adjacency matrix, respectively.

For a FDI network, if $n_{k}$ nodes have the same degree $k$, the degree distribution $p(k)$ is defined as $p(k)=n_{k} / n$, According to the paper published by Albert and Barabasi in the journal Science [28], if the degree distribution can be fit with the power law described in Equation (7), the network is a scale-free network. One of the most obvious features of a scale-free network is choosing best; that is, each new node in the network will preferentially connect to those nodes with a large degree, and then the degrees of these nodes with a large degree will become larger and larger. When the number of nodes grows to a certain number, most nodes in the network will have fewer connected relationships, while a few nodes have a large number of connected edges. These minority hub nodes often play a leading role in scale-free networks.

$$
P(k) \sim k^{-}
$$

\subsubsection{Node Strength}

In a directed weighted complex network, the node strength $S$ represents the sum of all the edge weights of node $i$, which is used to quantitatively measure the strength of the relationship between node $i$ and other nodes. The node strength is divided into in-strength and out-strength. In the Belt and Road FDI network, the in-strength of node $i$ indicates the sum of flows that all countries have invested in country $i$; the out-strength of node $i$ indicates the sum of flows that country $i$ has directly invested in all countries. The in-strength and out-strength of node $i$ are defined as follows by Equations (8) and (9) [27].

$$
\begin{aligned}
& S_{i}^{\text {in }}=\sum_{j=1}^{n} w_{j i} \\
& S_{i}^{\text {out }}=\sum_{j=1}^{n} w_{i j}
\end{aligned}
$$


where $w_{j i}$ is the weight of the edge from node $j$ to node $i$, and $w_{i j}$ is the weight of the edge from node $i$ to node $j$.

\subsection{Data}

Before data collection and processing, the following issues were mainly considered: first, since the Belt and Road is an open international regional economic cooperation system, there is currently no clear boundary area for the countries included in this system [29], so which countries' bilateral data should be collected? Second, how should the missing data of some countries be dealt with? Third, the country sample size needed to be as large as possible to achieve statistical significance.

As a result, this paper first referred to the research of many scholars on the Belt and Road initiative, and then identified and selected 65 countries along the Belt and Road [30,31]. In the process of collecting and collating the bilateral FDI flows data of these countries, it was found that in the 2001 and 2002, the data of most countries were missing. In 2003-2017, the bilateral FDI flows data of some countries were incomplete for a long period. Therefore, in order to ensure the integrity and continuity of statistical data, this study excluded all data from 2001 and 2002, and also eliminated those countries where bilateral FDI flows data were absent over a long period. In the end, the bilateral FDI flows data (in millions of US dollars) from 50 countries in 2003-2017 were selected (see Appendix A Table A1 for details). The data summary of FDI flows is shown in Table 1.

Table 1. Descriptive statistic of foreign direct investment (FDI) flows.

\begin{tabular}{cccccc}
\hline Variable & Obs & Mean & Std. Dev. & Min & Max \\
\hline FDI flows & 8560 & 82.091 & 677.314 & $-17,400$ & 17,163 \\
China inflows & 559 & 152.086 & 792.864 & 0 & 7228.72 \\
China outflows & 599 & 200.84 & 654.476 & -2510.27 & $10,452.48$ \\
\hline
\end{tabular}

\section{Analysis of Belt and Road Foreign Direct Investment Network}

In order to present the research conclusions in a more ordered and clear way, this paper comprehensively analyzed the calculation results of the above indicators, and expanded as follows: (1) structure of the FDI network; (2) behavior of the FDI network; (3) evolution of the FDI network.

\subsection{Structure of the FDI Network}

Structural features were mainly analyzed from three dimensions: geospatial structure, network topology, and flows structure. The geospatial structure mainly displayed the overall relationship structure of direct investment of countries along the Belt and Road on a two-dimensional map through geographic visualization, as shown in Figure 1. As can be seen from Figure 1, Central and Eastern Europe was the most densely connected area of the Belt and Road FDI network. It showed that the investment status of Central and Eastern European countries in the area along the "Belt and Road" was very important, and mutual investment between these countries was also very close, followed by Southeast Asia and China; Southeast Asia was closely connected with China and some countries in West Asia. China had connections with countries in all regions. This indicates that China's investment cooperation is very extensive. In the West Asia region, some countries, (for example, Saudi Arabia, Turkey, Iran and etc.) were more closely connected with Central and Eastern Europe and Southeast Asia countries.

Finally, in the area of South Asia and Central Asia, South Asian countries had obvious mutual investment relationships, such as between India, Bangladesh, and Sri Lanka. The number of connections between Central Asia and other regions was small, which indicates that these Central Asia countries have weak relationships of investment cooperation with other regions. However, Kazakhstan was the country with the most prominent investment connection in Central Asia. It had close relationships of cooperation with some countries in Central and Eastern Europe and West Asia. If the connected lines 
in Figure 1 are regarded as "investment friend" relationships, it is obvious that China had the largest number of "investment friends".

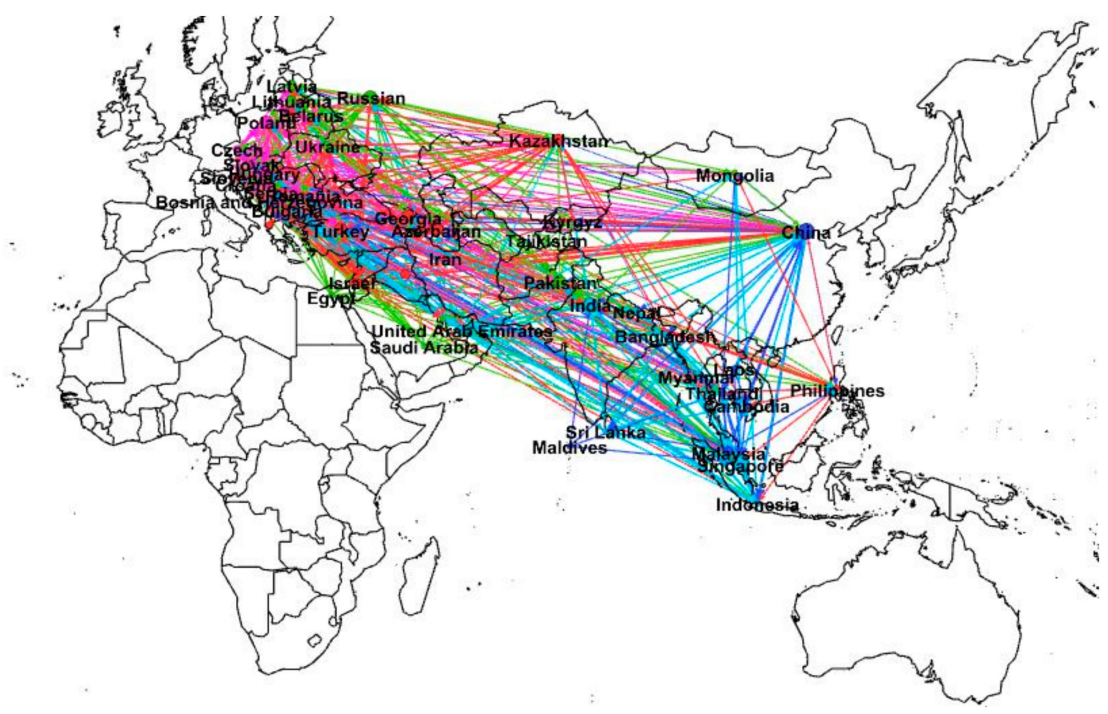

Figure 1. Geospatial structure of the “Belt and Road” FDI network in 2017.

This paper selected the node degree index in the FDI network to show the main topology of the network, as shown in Figure 2 (due to the limitation of space, only the main topology of some years is displayed). As can be seen from the following topology diagrams, from 2008 to 2012, Central and Eastern European countries such as the Czech Republic, Poland, Hungary, Bulgaria, etc. were consistently a major component of the FDI network topology. The other part was composed of regional powers such as China, Russia, Turkey, India, Saudi Arabia, and other countries.

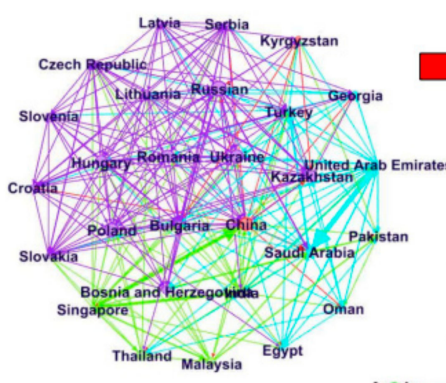

(a)

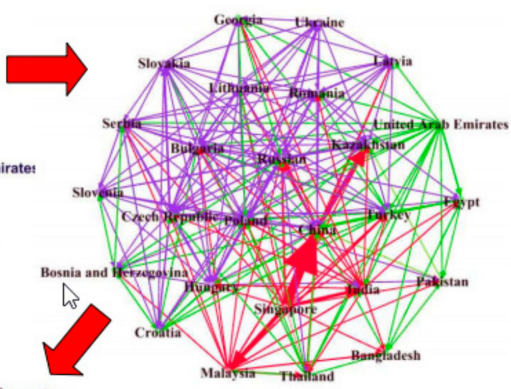

(b)

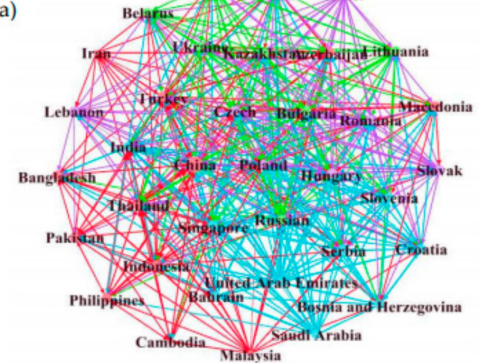

(c)

Figure 2. Main topology structure of network in different years: (a) 2008; (b) 2012; (c) 2017.

In 2017, some countries with smaller GDP aggregates also entered the main topological structure, such as Indonesia, Azerbaijan, Israel, Macedonia, etc. This demonstrates that the border of the FDI network between countries along the route has been expanding, and that investment links have become closer. In addition, comparing the three topological maps in Figure 2, it was concluded that although 
eight years had passed, the main topology of the Belt and Road FDI network had not changed very significantly, and it was still composed by the main countries of Central and Eastern Europe and regional powers. The Belt and Road FDI network structure has evolved very slowly.

Additionally, from a religious point of view, it was found that there were two very noticeable religious investment camps in the Belt and Road regions. The internal investment behavior of each camp was obvious. By comparing the colors of the connections between nodes, it was found that these countries were in a relatively independent state before the Belt and Road initiative. That is to say, Christian countries invested less in Islamic countries and more in Christian countries. Islamic countries had the same characteristic. However, since the Belt and Road initiative, the Christian countries and Islamic countries have presented a trend of investment integration, and the Islamic countries have shown a positive and prominent attitude in this trend of integration.

In order to measure the flow differences of the FDI network structure, this paper constructed the OFDI ratio index of the countries, defined as in Equation (10):

$$
R i=\frac{\sum_{j=1}^{n}\left(W_{i j}\right)}{\sum_{i=1}^{n}\left(\sum_{j=1}^{n} W_{i j}\right)}
$$

The outward-FDI flows rate is the ratio of the outward direct investment flows of the node $i$ to the sum of the outward direct investment flows of all the nodes in the network. By comparing the values of $R i$ in various countries, the differences of flows were analyzed. According to the calculations, the outward-FDI flows and rates of each country from 2003 through 2017 are shown in Table 2.

Table 2. Outward foreign direct investment flows of some countries in 2015.

\begin{tabular}{cccc}
\hline Rank & Country & Outward-FDI Flows (Millions of USD) & Ri \\
\hline 1 & China & 2599 & $26.197 \%$ \\
2 & Israel & 1445 & $14.565 \%$ \\
3 & Saudi Arabia & 824 & $8.306 \%$ \\
4 & Poland & 678 & $6.834 \%$ \\
5 & Malaysia & 618 & $6.229 \%$ \\
6 & Azerbaijan & 601 & $6.058 \%$ \\
7 & Singapore & 593 & $5.977 \%$ \\
8 & Thailand & 544 & $5.483 \%$ \\
9 & Turkey & 544 & $5.483 \%$ \\
10 & Iran & 438 & $4.415 \%$ \\
11 & Lebanon & 270 & $2.721 \%$ \\
12 & Lithuania & 242 & $2.439 \%$ \\
\hline
\end{tabular}

Note: Due to space limitations, only the OFDI flows and Ri of the top 12 node countries in the 2015 FDI network are given.

It can be seen from Table 2 that there was a significant gap in the flow of outward foreign direct investment between the countries in the FDI network structure, and the distribution of flows was not balanced. In addition, the annual outward-FDI flow rate $R i$ value of each country was cumulated and the cumulative percentage of corresponding country numbers was calculated, as shown in Figure 3.

It shows that in each year, the accumulated outward foreign direct investment flows of the top $16 \%$ countries reached $80 \%$ of the total outward foreign direct investment flows in the FDI network. This shows that the "Pareto Law" was very obvious in the FDI network from 2003 to 2012. That is to say, a small number of countries along the Belt and Road route controlled most of the investment flow resources. 


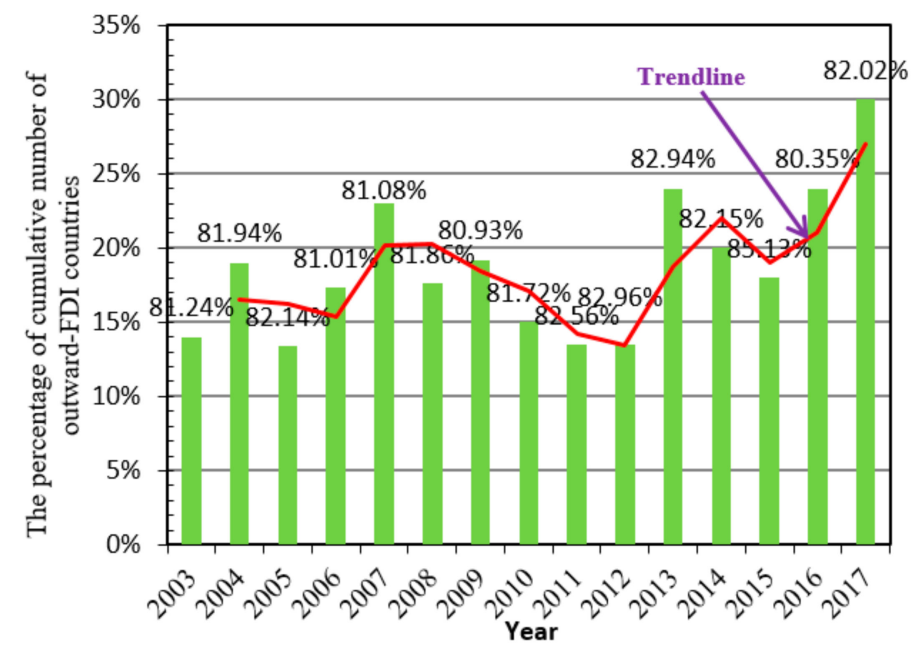

Figure 3. Percentage chart of the cumulative number of outward-FDI countries.

However, since the Belt and Road initiative, this phenomenon has begun to weaken. Each year, the accumulated outward foreign direct investment flows of the top 23\% countries have reached $80 \%$ of the total outward foreign direct investment flows in the FDI network. In just five years, it increased by about 7 percentage points. This indicates that after the Belt and Road initiative, the foreign direct investment needs of many countries along the Belt and Road route expanded significantly, and the evolution of the Belt and Road investment network gradually began to shift from "very few countries in control" to "multiple countries participating together".

\subsection{Behaviors of the FDI Network}

The clustering coefficient of a node measures the connection behavior between the node and its neighboring nodes. The degree distribution of the network reflects whether the nodes in the network perform preferential selection behavior. Therefore, the integration of the above two indicators can reflect the overall behavioral characteristics of FDI networks along the Belt and Road countries. When calculating the clustering coefficients of each node over the years, it was found that the clustering coefficient values of countries with small node degrees were usually large, and the clustering coefficient values of countries with large node degrees were usually small, as shown in Tables 3 and 4.

Table 3. Node degree and clustering coefficient of some countries.

\begin{tabular}{cccccccc}
\hline Country & Jordan & Mongolia & Kyrgyzstan & Nepal & Syrian & Iraq & Afghanistan \\
\hline Node degree & 13 & 13 & 10 & 9 & 7 & 6 & 4 \\
\hline Average clustering coefficient & 0.65 & 0.75 & 0.57 & 0.76 & 0.69 & 0.67 & 0.92 \\
\hline
\end{tabular}

Table 4. Node degree and clustering coefficient of some countries.

\begin{tabular}{ccccccccc}
\hline Country & China & Singapore & Russian & Poland & Turkey & Thailand & India \\
\hline Node degree & 70 & 61 & 58 & 54 & 51 & 50 & 47 \\
\hline Average clustering coefficient & 0.29 & 0.36 & 0.39 & 0.47 & 0.38 & 0.33 & 0.40 \\
\hline
\end{tabular}

This suggests that countries with small node degrees are generally inclined to establish mutual investment relations with neighboring countries, and are less likely to invest with non-neighboring countries across geographical distances. Countries with large node degrees usually invest not only in neighboring countries that are geographically close, but also choose to establish investment relationships with many non-neighboring countries. The countries with large node degrees are generally regional 
powers along the Belt and Road area, such as China, Singapore, Turkey, India, Russia, Poland, and other countries.

In addition, this paper observed that the node degrees and clustering coefficients of some countries in Central and Eastern Europe have always been larger, as shown by the circled area in Figure 4. This shows that these Central and Eastern European countries have always tended to make direct investments in other Central and Eastern European countries in the region, and have always maintained close investment links with other countries in the region. Although this behavioral trait weakened from 2008 to 2012, it was significantly enhanced in the 2013 to 2017. Therefore, from a long-term perspective, the strong clustering behavior exhibited by these Central and Eastern European countries has not changed much and is very stable.

(a)

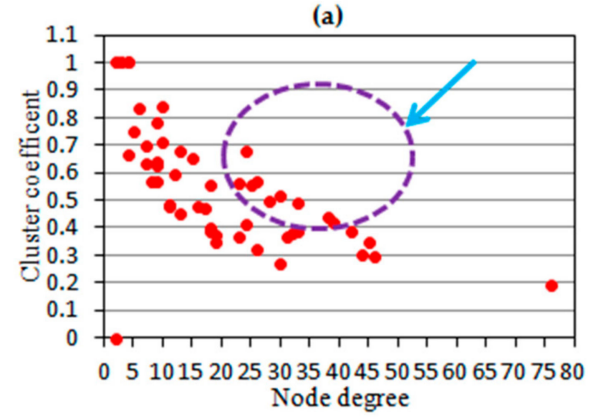

(c)

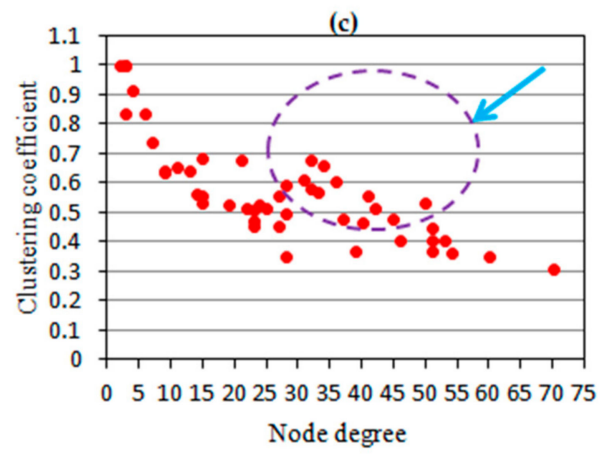

(b)

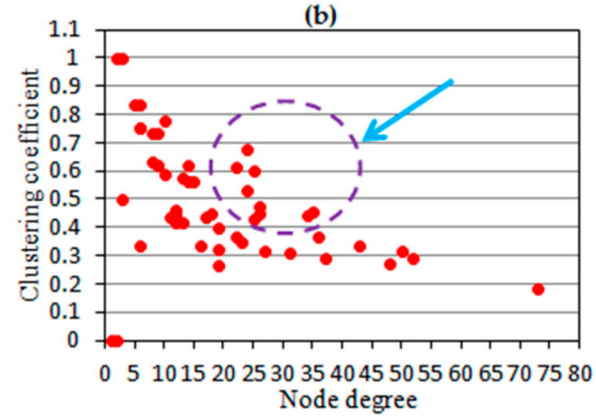

(d)

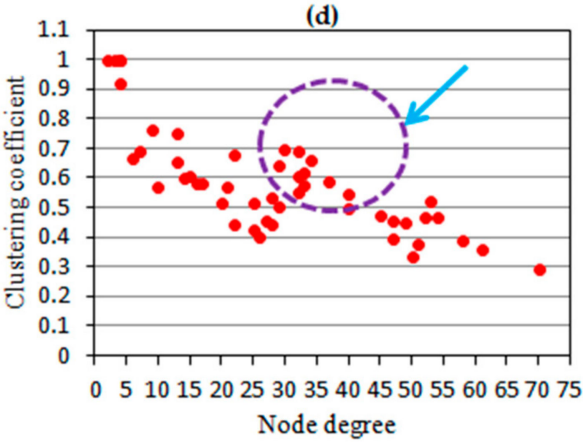

Figure 4. Node degree and cluster coefficient scatter plot in different years: (a) 2008; (b) 2012; (c) 2015; (d) 2017.

When analyzing the degree distribution, it was found that the results of the degree distribution over the years were not completely consistent with the power-law distribution function, but were more in line with the exponential distribution function. The findings were similar to the results of many scholars studying the degree distribution of international trade networks [32], as shown in Figure 5. This shows that the Belt and Road FDI network does not fully reflect the scale-free feature.

That is to say, not all newly invested countries will prefer to choose those countries with large node degrees. In other words, a generally popular investment destination does not necessarily attract the favor of newly-invested countries. For example, China is a popular country in the FDI network. In 2017, Macedonia joined the FDI investment network. When it chooses an investment destination in the network, it will not give priority to China. The behavior of choosing the best is not obvious in countries with small node degrees. On the contrary, because of smaller economies, limited capital, geographical distances, and due to differences in national cultures, they are more inclined to choose neighboring countries with small node degrees in which to invest. 


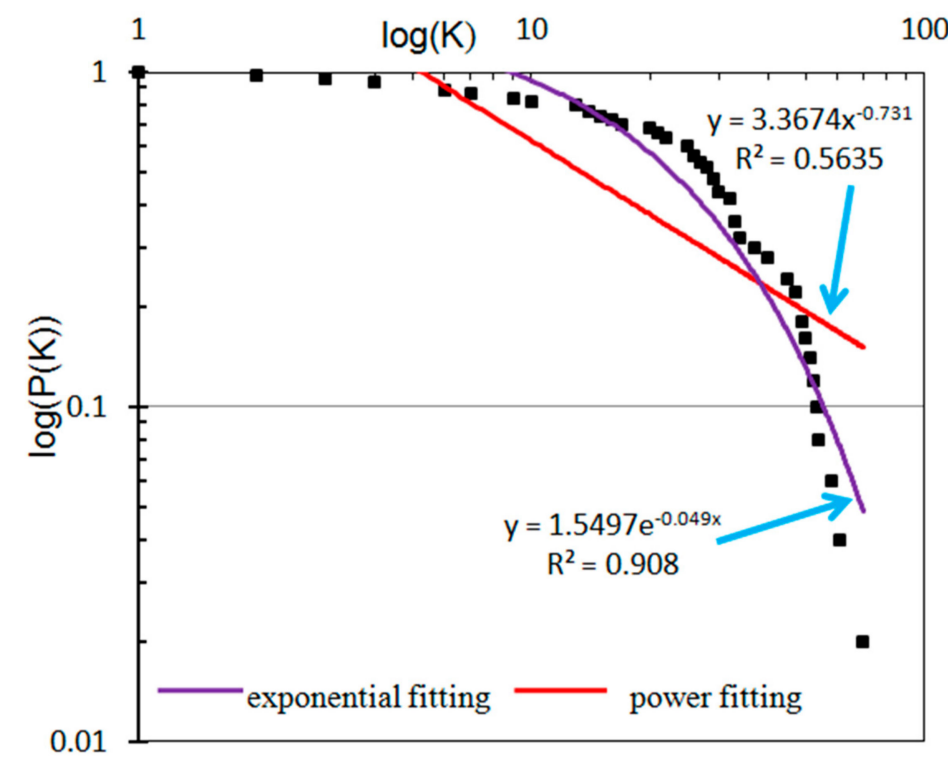

Figure 5. Logarithmic coordinate diagram of cumulative degree distribution of nodes.

\subsection{Evolution of the Belt and Road FDI network}

\subsubsection{The Evolution of the Overall Network}

In order to quantitatively measure the evolutionary trend, this paper calculated the network density value and clustering coefficient from 2003 to 2017, as shown in Figure 6. It can be seen from Figure 6 that during the 10 years from 2003 to 2012, the tightness of the FDI network structure and the overall level of grouping were not high. This indicates that the connectivity and cooperation between countries in the system were poor, and the grouping trend of member countries within the system was not obvious.

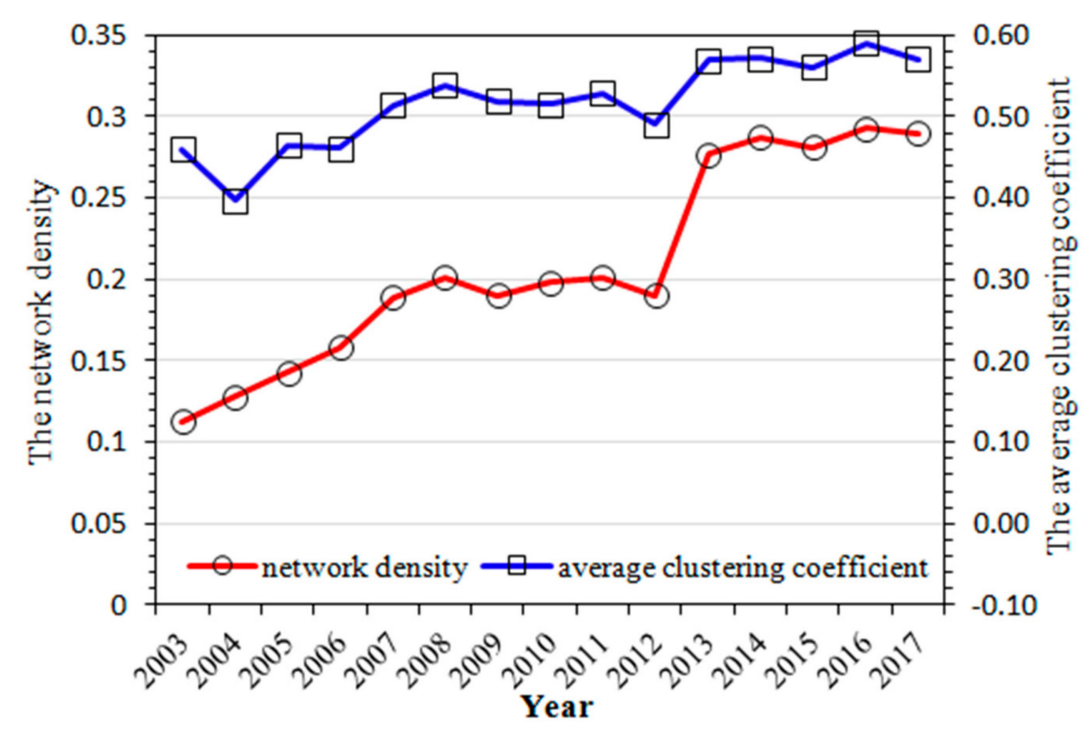

Figure 6. FDI network density and average clustering coefficient.

However, since 2013, the network density value has increased evidently. In the 10 years from 2003 to 2012 , the density of foreign direct investment networks increased by approximately $47.8 \%$, while in the five years from 2013 to 2017, the network density value also increased by approximately 47\%. This shows that after the Belt and Road initiative, direct investment links between countries along the Belt and Road regions were greatly strengthened. In addition, the network average clustering 
coefficient also enhanced significantly, and the overall level continuously improved. This shows that the internal grouping degree of the FDI network continuously strengthened, and regional powers along the Belt and Road area formed their own investment groups. The chain effect of changes in direct investment flows between countries within the group also gradually increased.

\subsubsection{The Evolution of Chinese FDI Flows in the Belt and Road FDI Network}

China is the proponent of the Belt and Road initiative and is the main driving force for the practice of Belt and Road initiative. Therefore, the flow changes of Chinese investment in Belt and Road areas have an extremely important impact on the evolution of the Belt and Road FDI network. This study calculated the total FDI inflows of China and total outward-FDI flows of China in the Belt and Road network from 2003-2017, as shown in Figure 7.

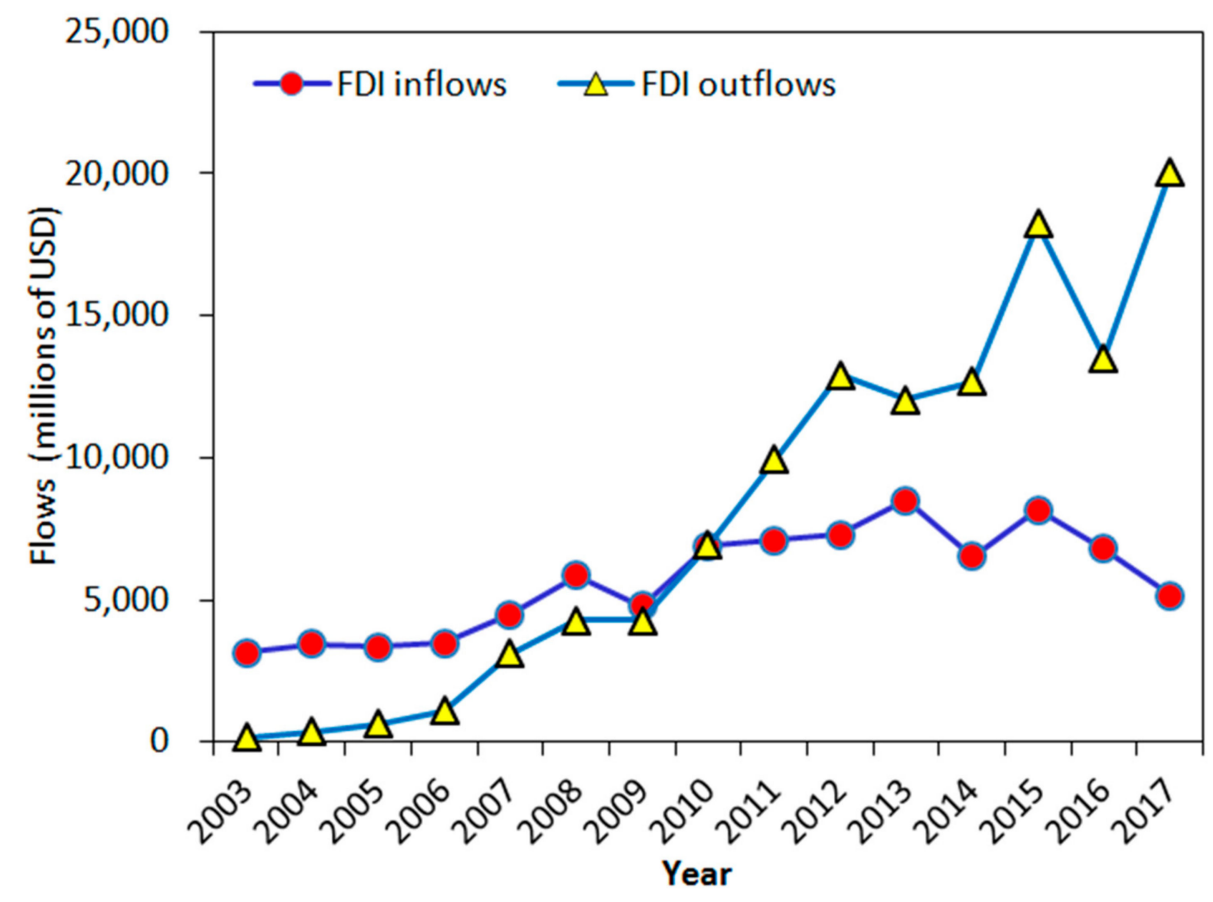

Figure 7. FDI inflows and outflows of China from 2003-2017.

As can be seen from Figure 7, outward foreign direct investment generally showed a growth trend, and the growth rate was very high. In comparison, the growth trend of foreign direct investment inflows from countries along the route was not obvious, and the growth rate was not large. There was even a continuous downward trend in 2015-2017. This showed that direct investment to China from Belt and Road countries is still at a low level, and it indicated that reciprocal investment between China and these countries along the line is in a state of serious imbalance. For China, the prospect of introducing foreign direct investment from the Belt and Road regions is not very optimistic.

\section{Analysis of the Influencing Factors of the Belt and Road FDI Network Based on QAP Regression Analysis Method}

After analyzing and revealing the pattern of the Belt and Road FDI network, this paper further explored and studied the influencing factors of the formation process of the FDI network through the method of QAP regression analysis, in order to answer the following question: What factors influence, and how do these factors impact and contribute to the formation of, the pattern of the investment network along the Belt and Road regions? 


\subsection{QAP Regression Analysis Method}

Since the quadratic assignment procedure (QAP) can effectively solve the autocorrelation problem of network data, Krackhardt applied it to the multiple regression analysis of network data and formed the QAP multiple regression analysis method [33]. The QAP regression analysis method first calculates the regression coefficient between a matrix and multiple matrices and its significance, and then tests the causality between matrices. It mainly implements this calculation process by four steps.

First, a standard multiple regression analysis is performed on the elements in the independent variable matrix and the corresponding elements in the dependent variable matrix. Second, thousands of random permutations are performed simultaneously for each row and column of the elements in the dependent variable matrix. Third, the regression coefficients are recalculated and all regression coefficients and R-square values are saved. Finally, the above steps are repeated hundreds of times to estimate the standard error. It should be noted that before performing QAP regression analysis, it must be ensured that all variables matrices are $\mathrm{N} \times \mathrm{N}$ matrices [34].

Because QAP regression analysis is effectively able to solve the autocorrelation problem between network variables data, and can always control the deviation within a certain range and remain stable, many scholars have applied this method to research influencing factors of network patterns [35-37]. Using QAP regression analysis to study the factors affecting network patterns, the related network variables and hypotheses must be determined, then a QAP regression model constructed, and finally the Ucinet software can be used for the model and hypothesis test.

\subsection{Explanatory Variables Selection and Hypotheses}

As recognized by many scholars studying FDI $[10,38,39]$, the eclectic theory of international production proposed by Dunning deeply explains the motivations of foreign direct investment $[40,41]$. This theory creatively incorporates "location advantage" into the framework of foreign direct investment analysis, and believes that there are three main motives for the OFDI of enterprises: (1) foreign market seeking; (2) efficiency (cost reduction) seeking; and (3) resource seeking. In addition, with the application of the gravity model in international economic research [42-44], geographic distance has also been found to be an important factor affecting OFDI $[13,38,45]$. Therefore, this paper combined the eclectic theory of international production and the investment gravity model, referred to the existing research, and then proposed the relevant explanatory variables.

\subsubsection{Economic Development Level}

In the previous FDI research literature, the level of national economic development has been undoubtedly considered one of the most important macro variables affecting FDI inflows [10,46,47]. The level of a country's economic development (usually expressed in terms of GDP or per capita GDP) reflects both the size of its economy and the size of its consumer market. Generally speaking, when a country is at a high level of economic development, it shows that the total value of products or services produced is high, and the scale of consumer market is also large. The probability of enterprise investment returns will be high. Thus, the higher the level of economic development of a country, the easier it is to attract foreign direct investment. When the economic development levels of all node countries in an FDI network are not balanced and the gaps are large, enterprises will give priority to those countries with high economic development level for investment, rather than countries with low economic development levels, in order to reduce the uncertainty of investment returns. Thus, Hypothesis 1 was proposed:

Hypothesis 1. The gap between the economic development levels of these countries that along the Belt and Road area is affecting and contributing to the formation of the pattern of the FDI network. 


\subsubsection{Bilateral Trade}

Trade links between two countries often lead to investment links. According to Mundell's research [48], when the volume of trade between the host country and the home country is very large, the host government will set up relevant trade barriers to the home country enterprises, so as to protect the development interests of domestic enterprises. In order to avoid barriers and possible high tariffs, home-country enterprises usually make direct investment in the host country and then produce products in the host country. Therefore, this paper hypothesized that:

Hypothesis 2. Bilateral trade between the countries along the Belt and Road is affecting and contributing to the formation of the pattern of the FDI network.

\subsubsection{Natural Resources}

Resource-seeking is one of the important motives of foreign direct investment [40]. Numerous studies have proven that companies in countries with scarce natural resources often invest heavily in countries with abundant natural resources to meet their demands for natural resources $[39,49,50]$. For example, many countries with poor petroleum resources have invested in countries with rich oil resources in the Middle East, so as to meet their own petroleum resource needs, such as China, Japan, South Korea, et al. Resource-seeking investment is particularly evident in Chinese enterprises. Research has shown that there is a significant positive correlation between China's outward-FDI and the natural resources, and Chinese companies prefer the investment of fossil fuel resources [10,45]. This reflects that the differences of natural resources between countries will have an important impact on the choice of investment location of enterprises, and then affect the investment flows between countries. Therefore, the following Hypothesis 3 was derived:

Hypothesis 3. The gap in natural resources between the Belt and Road countries is affecting and contributing to the formation of the pattern of the FDI network.

\subsubsection{Tax Burden of Enterprise}

Corporate tax burden is an important factor affecting a country's attraction to foreign investors, and the factor has attracted the attention of researchers [51]. Before choosing a country in which to invest, companies will pay attention to the tax rate that the government requires companies to pay. In general, high taxes mean that companies have to pay a large part of their profits to the government, thus reducing the actual profits of the company. Low taxes mean that companies only need to hand over a small part of their profits to the government, and companies can retain most of their profits. Therefore, high-tax countries will have a negative effect on attracting FDI, while low-tax countries will have a positive effect on attracting FDI. For example, scholars have found that many enterprises tend to invest in such "tax havens" as the British Virgin Islands and the Cayman Islands. When the gap of tax levels between countries is large, enterprises will give priority to those countries with low taxation for their investments, rather than high taxation countries, in order to increase the profits of investment. Thus, Hypothesis 4 was developed:

Hypothesis 4. The tax burden gap between countries along the Belt and Road is affecting and contributed to the formation of the pattern of the FDI network.

\subsubsection{Geographical Distance}

According to the gravity model applied by many scholars when studying the location determinants of enterprises' outward direct investment, geographical distance is one of the important factors affecting the location selection of enterprises' OFDI $[36,39]$. To some extent, the existence of distance means the existence of differences. The size of distance also means the size of differences, and so does 
geographical distance. Generally speaking, the greater the geographical distance is, the greater the differences between countries are, especially in the cultural aspects of home and host countries. This may bring cultural inadaptability to enterprises. In addition, a smaller geographic distance will also reduce the cost of obtaining effective information from the host country market. Therefore, the fifth hypothesis was as follows:

Hypothesis 5. The gap of geographical distance between countries along the Belt and Road is affecting and contributing to the formation of the pattern of the FDI network.

\subsection{Variable Description and Data}

\subsubsection{Dependent Variable}

The dependent variable is the matrix of bilateral FDI stocks of country $i$ and country $j$ (from 2009-2016). It is necessary to explain why FDI stocks were chosen instead of FDI flows. The main reason is that the bilateral FDI stocks between countries can more accurately reflect the long-term characteristics of mutual investment behavior among countries. FDI flows only reflect the mutual investment situation of different countries in a certain year, and the fluctuation of FDI flows is large, with obvious short-term characteristics. Additionally, many scholars have also used FDI stocks as a measure of dependent variables when studying the determinants of FDI location [45,52-54]. Therefore, this paper chose bilateral FDI stock between countries as the measurement of dependent variable.

\subsubsection{Independent Variables}

The independent variables were those influencing factors in the above hypotheses, and the measurement of each independent variable was as follows. This paper measured the economic development level using GDP values. Generally speaking, the higher the economic development level is, the greater the GDP value of a country is. Additionally, the GDP value can also reflect the size of a country's consumer market. The larger the GDP is, the greater the size of the country's consumer market is. Therefore, when the difference in GDP between countries is larger, it indicates that the level of economic development and market size between countries is also larger.

A country's total import trade from another country was used to measure the bilateral trade between countries. Generally speaking, when the import trade volume of country A from country B is larger, it is easier for government $A$ to set tariff barriers or impose punitive tariffs on enterprises in country B to protect the interests of domestic enterprises (the recent trade measures taken by the US government have fully proven this point.). If country B enterprises make investments to construct factories and produce products in country A, it will greatly reduce the tariff risk and decrease the original trade and transportation costs. Therefore, the larger the bilateral trade volume between countries, the more direct investment.

The natural resource was measured as the share of natural resource rent in GDP (\%). If the ratio of natural resource rent to GDP is greater, it means that the country's economic development depends more on natural resources. Therefore, the greater the gap in this ratio, the greater the gap in the amount of natural resources between countries.

The tax burden of enterprise was measured by the total tax rate levied by governments on domestic companies. The higher the total tax rate, the greater the corporate tax burden. The greater the difference in the total tax rate between countries, the greater the gap in tax burdens that companies bear. According to the CEPII database, the geographical distance between countries is measured by the geographical location gap between the largest population cities in each country. The greater the geographical distance is, the greater the cultural and linguistic differences between countries are. Transportation costs will also be higher. 


\subsubsection{Data}

Among the above independent variables, bilateral FDI stock data between countries were derived from the International Monetary Fund statistical (IMF) database. The data of the economic development level, the institutional quality, the natural resources, and the total tax rate were all derived from the World Bank database. Data on bilateral trade volume were derived from the UN Cometrade database. Geographical distance data came from the CEPII database. The data summary of dependent variable and independent variables is shown in Table 5. In order to ensure the completeness, correspondence, and consistency of the relevant variable data of the sample countries in all databases, after screening and eliminating, this paper finally collected the FDI stocks statistics of 34 countries from 2009 to 2016. At the same time, the relevant data of all dependent variables were also collected. Based on these data, corresponding matrices of variables were established. Additionally, in order to eliminate the dimension difference of different variables, this paper standardized the data of these variables. The standardized processing Equation (11) used is as follows:

$$
X_{\text {standardization }}=\frac{X_{j}-X_{\min }}{X_{\max }-X_{\min }}
$$

Table 5. Descriptive statistics of variables.

\begin{tabular}{cccccc}
\hline Variable & Obs. & Mean & Std. Dev. & Min & Max \\
\hline Trade & 34 & $3.33 \times 10^{10}$ & $4.24 \times 10^{10}$ & $1.55 \times 09^{10}$ & $1.80 \times 11^{10}$ \\
GDP & 34 & $5.82 \times 11^{10}$ & $1.93 \times 12^{10}$ & $6.81 \times 09^{10}$ & $1.12 \times 13^{10}$ \\
Distance & 1122 & 4186.68 & 2915.227 & 117.345 & 10705.36 \\
Tax & 34 & 36.75 & 12.878 & 13.5 & 68.2 \\
Resource & 34 & 3.015 & 5.299 & 0 & 25.177 \\
FDI stock & 34 & $18,146.38$ & $32,452.24$ & 467.275 & 134,000 \\
\hline
\end{tabular}

\subsection{The QAP Multiple Regression Model}

Constructing a QAP regression model is essentially similar to constructing a multiple regression model. First, we need to determine the corresponding dependent variables and independent variables. According to the eclectic theory of international production and the economic gravity model $[41,44,55,56]$, it is known that the factors affecting a country's bilateral direct investment mainly include economic development level, corporate tax burden, natural resource endowment, bilateral trade, and geographical distance between countries. Through hypothesis deduction and reasoning of the above influencing factors, this paper further inferred that bilateral trade and geographical distance, as well as the gap of economic development and corporate tax burden and natural resources, affect bilateral direct investment between countries.

Therefore, this paper regarded the bilateral FDI stocks between countries as the dependent variable of the QAP regression model, and took the economic development level gap, corporate tax burden gap, natural resource gap, bilateral trade, and geographical distance as independent variables. Referring to the study by Krackhardt on the QAP multiple regression model [57], the following model was constructed:

$$
\begin{gathered}
F D I_{i j}=\beta_{0}+\beta_{1} G D P_{i j}+\beta_{2} \text { Tax }_{i j}+\beta_{3} \text { Resource }_{i j}+\beta_{4} \text { Trade }_{i j} \\
+\beta_{5} \text { Dist }_{i j}+\varepsilon_{i j}
\end{gathered}
$$

In this model, $F D I_{i j}$ represents the FDI stock matrix between country $i$ and country $j(I=1,2, \ldots$ $n, j=1,2,3 \ldots n) . G D P_{i j}$ represents the difference matrix of economic development levels between country $i$ and country $j$. Trade $e_{i j}$ represents the trade volume matrix between country $i$ and country $j$. Resource $_{i j}$ represents the difference matrix of natural resources between country $i$ and country $j$. Tax $i j$ represents the tax difference matrix between country $i$ and country $j$. Dist $t_{i j}$ represents the geographic distance matrix between country $i$ and country $j$. 


\section{Empirical Results}

\subsection{Preliminary Test}

Before the QAP regression analysis, the correlation analysis of each variable matrix was carried out to determine whether there was a potential multi-collinearity problem between the variable data. The analysis results are shown in Table 6. As can be seen from Table 6, none of the correlation coefficients exceeded 0.5 , which means that there were no serious multicollinearity problems among these main variables. Therefore, the QAP regression analysis would be able to test the above hypotheses and the model effectively.

Table 6. Correlation coefficients.

\begin{tabular}{|c|c|c|c|c|c|c|}
\hline Variables & $F D I_{i j}$ & $G D P_{i j}$ & $\operatorname{Tax}_{i j}$ & Resource $_{i j}$ & Distance $_{i j}$ & Trade $_{i j}$ \\
\hline$F D I_{i j}$ & 1.000 & & & & & \\
\hline$G D P_{i j}$ & $\begin{array}{c}0.119 \\
(0.104)\end{array}$ & 1.000 & & & & \\
\hline $\operatorname{Tax}_{i j}$ & $\begin{array}{c}0.045 \\
(0.169)\end{array}$ & $\begin{array}{c}0.372 \\
(0.001)\end{array}$ & 1.000 & & & \\
\hline $\operatorname{Resource}_{i j}$ & $\begin{array}{l}-0.063 \\
(0.102)\end{array}$ & $\begin{array}{l}-0.072 \\
(0.373)\end{array}$ & $\begin{array}{l}-0.072 \\
(0.185)\end{array}$ & 1.000 & & \\
\hline$D i s \tan c e_{i j}$ & $\begin{array}{l}-0.245 \\
(0.000)\end{array}$ & $\begin{array}{c}0.173 \\
(0.095)\end{array}$ & $\begin{array}{c}0.063 \\
(0.154)\end{array}$ & $\begin{array}{c}0.081 \\
(0.200)\end{array}$ & 1.000 & \\
\hline Trade $_{i j}$ & $\begin{array}{c}0.601 \\
(0.000)\end{array}$ & $\begin{array}{c}0.432 \\
(0.004)\end{array}$ & $\begin{array}{c}0.116 \\
(0.062)\end{array}$ & $\begin{array}{l}-0.094 \\
(0.034)\end{array}$ & $\begin{array}{c}-0.237 \\
0.000\end{array}$ & 1.000 \\
\hline
\end{tabular}

\subsection{QAP Regression Results}

In this paper, 5000 random repetitions were selected for regression and the results are shown in Table 7. Table 7 shows that the regression coefficient of GDP was negative and was significant at the $1 \%$ level. This empirical result confirmed Hypothesis 1 that the gap between the economic development levels of the Belt and Road countries is affecting and contributing to the formation of the pattern of the FDI network. When the difference in economic development levels between countries was greater, the amount of bilateral FDI stocks between countries was less. This also means that when the gap in economic development between countries in the Belt and Road region is greater, mutual investment behavior between countries will become less likely to occur. In addition, as mentioned earlier, the GDP of a country also represents the size of the country's consumer market. The greater the difference in GDP, the greater the gap in the size of the consumer market between two countries. As a result, it was also learned from the regression results that the larger the gap in the size of the consumer market, the less bilateral FDI stock among countries. It was also deduced that enterprise investment of the Belt and Road countries belongs to "market-seeking" investment.

The regression coefficient of the tax difference variable was positive, but was insignificant. This meant that $\mathrm{H} 2$ had to be rejected. That is to say, the tax burden of enterprise did not affect the formation of the pattern of the FDI network. This suggests that, on the whole, the tax gap was not the main factor that makes investment linkages in countries in the region, and most countries do not show obvious tax avoidance when investing abroad. However, to some extent, its positive regression coefficient could still reflect that companies of some countries in the region are willing to invest in those countries with low corporate tax burdens.

The natural resource gap variable did not pass the significance level test; hypothesis $\mathrm{H} 4$ was rejected. This indicated that the formation of the pattern of the FDI network is not affected by the natural resource gaps among these countries. Moreover, it implied that enterprises in the countries along the route do not pay much attention to the natural resources of the host country when they invest 
in the area. On the other hand, this also shows that the Belt and Road initiative is not an initiative to plunder the natural resources of countries along the route.

Table 7. Quadratic assignment procedure (QAP) regression analysis results

\begin{tabular}{|c|c|c|c|c|c|c|}
\hline Variables & $\begin{array}{l}\text { Un-Standardized } \\
\text { Regression } \\
\text { Coefficient }\end{array}$ & $\begin{array}{l}\text { Standardized } \\
\text { Regression } \\
\text { Coefficient }\end{array}$ & $\begin{array}{c}\text { Significant } \\
\text { Probability Value }\end{array}$ & $\begin{array}{l}\text { Proportion } \\
\text { As Large }\end{array}$ & $\begin{array}{l}\text { Proportion } \\
\text { As Small }\end{array}$ & R-Square \\
\hline$G D P_{i j}$ & -0.142 & $-0.165 * * *$ & 0.000 & 1.000 & 0.000 & \\
\hline $\operatorname{Tax}_{i j}$ & 0.027 & 0.035 & 0.137 & 0.137 & 0.863 & \\
\hline Resource $_{i j}$ & -0.005 & -0.006 & 0.515 & 0.485 & 0.515 & 0.390 \\
\hline Trade $_{i j}$ & 0.594 & $0.653 * * *$ & 0.000 & 0.000 & 1.000 & \\
\hline$D i s \tan c e_{i j}$ & -0.039 & $-0.063 * *$ & 0.029 & 0.971 & 0.029 & \\
\hline $\mathrm{N}$ & & & 1122 & & & \\
\hline
\end{tabular}

The regression coefficient of trade volume was positive, and it passed the significance test at the $1 \%$ level. The findings supported Hypothesis 4 that bilateral trade has influenced and contributed to the formation of the FDI network structure and behavior of the Belt and Road areas. The greater the bilateral trade volume between countries, the greater the stock of bilateral FDI between countries. This result also showed that bilateral trade between countries can attract direct foreign investment between countries. Moreover, the trade flows in the area along the Belt and Road have a significant pulling effect on investment. In addition, comparing the regression coefficients of other variables showed that the regression coefficient of the trade variable was the largest. This means that this variable has had the most prominent impact on the formation of the pattern of the investment network along the Belt and Road regions.

The regression coefficient of the geographical distance was negative and was significant at the $5 \%$ level. Thus, Hypothesis 2 was supported. That is to say, the gap of geographical distance between countries along the Belt and Road is affecting and contributing to the formation of FDI network pattern. Geographical distance has a significant negative effect on bilateral FDI between countries. The greater the geographical distance, the less stock of FDI between countries. This indicates that enterprises are more inclined to invest in host countries that are geographically close to their home country in order to reduce the transportation costs and cultural difference risks caused by geographic distance. This finding was also in line with Yang et al. [45,53].

\section{Discussion}

Although the above results have been carefully analyzed, this paper believes that there are still two aspects worthy of further discussion. First of all, by comparing the existing literature on the Belt and Road trade network research, it was found that the Belt and Road regional investment network has a high consistency with the Belt and Road regional trade network. The Belt and Road trade network shows obvious regional internalization trade characteristics. For example, bilateral trade between countries in Central and Eastern Europe is very close, but trade links with other regions are relatively weak. Countries in Southeast Asia and West Asia also showed similar characteristics. This shows that the degree of economic integration among the countries within the sub-regions of the Belt and Road region is very high, and the economic cooperation among the countries within sub-regions is also very close. From the point of view of geography and history, this phenomenon may be caused by historical and geopolitical factors. However, from the perspective of a complex system network, it was not possible to effectively explain the reasons why the two networks exhibit consistency. Future research could explore this issue in depth.

Second, trade, market, and geographic distance are important factors affecting the bilateral investment behavior of countries along the Belt and Road. Among them, the impact of trade is the most prominent. This result further highlights the indivisibility of investment and trade. This further suggests that scholars must consider investment factors when studying trade issues between countries. 
In addition, this result showed the applicability of the eclectic theory of international production and the economic gravity model in economic network research.

In fact, many studies on economic networks have not gone deep into the theoretical aspects, and most of them have remained at the level of feature analysis of economic networks. The mechanism for the formation of such network is rarely discussed. There are many reasons for this, and the lack of economic theory is an important reason. Therefore, we believe that in future research, more theories need to be developed to explore the internal mechanisms of economic network formation in more depth.

However, this article also has some inadequacies. For example, FDI data of 15 countries was missing. In addition, there was a lack of in-depth discussion and analysis of the internal mechanisms underlying the formation of investment networks. These are also points for subsequent research.

\section{Conclusions and Policy Recommendations}

Against the background of insufficient research on foreign direct investment in the Belt and Road areas, from the perspective of complex system, this paper constructed and studied complex network models of the foreign direct investment network formed by 50 countries along the Belt and Road regions from 2003 to 2017. It revealed the pattern of the foreign direct investment network along the Belt and Road area, and quantitatively described the evolution of the Belt and Road FDI network. On this basis, we then further used the QAP multiple regression analysis method to study the main factors that have influenced the formation of the pattern of the foreign direct investment network in the Belt and Road region, and how these factors have affected the formation process. This provided new insights and findings for the study of FDI in the countries along the route. Finally, the article drew the following main conclusions.

First, the foreign direct investment network along the Belt and Road region is a typical complex network. From the perspective of geospatial structure, the investment ties between central and Eastern Europe are the most intensive, followed by Southeast Asia and China, then the Western Asia region, and finally, South Asia and Central Asia. From the perspective of topology, Central and Eastern European countries and some regional powers have always been the main components of the topology, and they play a key role in the evolution of the FDI network structure and the allocation of FDI resources. At the same time, there are two very noticeable religious investment camps in the Belt and Road regions. The two investment camps were relatively independent before 2013, but after the Belt and Road initiative, the two camps gradually showed a trend of investment integration; Islamic countries were particularly prominent and positive in this trend. In addition, from the perspective of flows structure, the distribution of FDI flows resources along the Belt and Road countries was seriously uneven. Since the Belt and Road initiative, this situation has improved. More and more countries are beginning to share investment flows in this region.

Second, in the Belt and Road FDI system, most small node countries will choose countries that are close to them as investment destinations, while large node countries will establish investment links with neighboring countries and non-contiguous countries, showing obvious expansion. Moreover, each newly added small node country will not give priority to countries with high economic development levels or more investment opportunities when investing aboard; instead, they prefer to establish investment links with neighboring countries with less geographical distance and cultural difference.

Third, the FDI network has undergone an evolution from loose to intensive, state investment differentiation to state investment grouping. The investment connection between node countries is getting closer and closer, especially since the Belt and Road initiative.

Fourth, economic development level, geographical distance, and bilateral trade are the main factors that have influenced the formation of the pattern of the Belt and Road regional investment network. Among these factors, bilateral trade has had the greatest impact on the process of the formation. Tax burden of enterprise and natural resources are not main influencing factors. 
Fifth, the economic development level and geographical distance have a significant negative effect on FDI in the Belt and Road region. That is, the greater the gap in economic development level, the less likely it is that bilateral investment behavior will occur between countries. The greater the geographical distance, the less likely it is also that bilateral investment behavior will occur. Bilateral trade has a significant positive effect on FDI in the Belt and Road region. This suggests that the greater the trade volume between two countries along the Belt and Road regions, the more likely it is that bilateral investment will occur. The OFDI of the Belt and Road countries is typical of "market-seeking" and "trade-driven" investment.

Based on the above conclusions, the following policy recommendations are put forward:

(1) Since the Belt and Road initiative, the regional investment pattern along the Belt and Road has undergone major changes. This change has promoted bilateral investment linkages between countries along the route and created valuable opportunities for countries to introduce foreign direct investment. Therefore, countries along the line should attach importance to and seize this opportunity to formulate relevant policies and achieve economic development by introducing more foreign direct investment.

(2) Countries along the route should optimize bilateral trade mechanisms in the area to maintain a multilateral trading system, and curb unilateral trade.

(3) Countries along the route should strengthen the construction of their own transportation infrastructures, and at the same time strengthen the transportation links between countries in order to reduce the cost of cross-border investment and trade. Additionally, governments should also support and promote cultural exchange, so that companies in their countries can better understand others' culture, thereby reducing the cultural incompatibility of foreign investors.

Author Contributions: Conceptualization, Q.H.; Methodology and Data curation, Q.H. and X.C.; Formal Analysis, Q.H.; Writing-Original Draft Preparation, Q.H. and X.C.

Funding: This research received no external funding.

Acknowledgments: The gratitude goes to associate Huajiao Li and Xiangyun Gao for their suggestions. Moreover, the authors would also like to thank the Craig Young, editor of the journal of Eurasian Geography and Economics, for his valuable advice. Finally, the authors would like to thank a friend, named Pengfei Yang, who provided a grammar proofreading service.

Conflicts of Interest: The authors declare no conflict of interest.

\section{Appendix A}

Table A1. List of 50 countries.

\begin{tabular}{ll}
\hline \multicolumn{1}{c}{ Area } & \multicolumn{1}{c}{ Selected Country } \\
\hline East Asia & China/Mongolia \\
\hline Central Asia & Kazakhstan/Kyrgyzstan/Tajikistan \\
\hline Southeast Asia & Laos/Singapore/Thailand/Malaysia/Indonesia/Cambodia/Philippines/ \\
\hline South Asia & India/Sri Lanka/Afghanistan/Pakistan/Bangladesh/Nepal/ Maldives \\
\hline Central and & Belarus/Bosnia and Herzegovina/Bulgaria/Croatia/Czech \\
Eastern Europe & Republic/Hungary/Latvia/Lithuania/ Poland/ Romania/ Serbia/ Slovakia/ Slovenia/ The \\
\hline Middle East and & Iran/Iraq/Israel/Jordan/Syrian Arab Republic/Turkey/Yemen/United Arab \\
West Asia & Emirates/Georgia/Azerbaijan/Egypt/Saudi Arabia/Bahrain/Lebanon \\
\hline
\end{tabular}

\section{References}

1. Tracy, E.F.; Shvarts, E.; Simonov, E.; Babenko, M. China's new Eurasian ambitions: The environmental risks of the Silk Road Economic Belt. Eurasian Geogr. Econ. 2017, 58, 56-88. [CrossRef] 
2. Peyrouse, S.; Raballand, G. Central Asia: The New Silk Road Initiative's questionable economic rationality. Eurasian Geogr. Econ. 2015, 56, 405-420. [CrossRef]

3. Reeves, J. China's Silk Road Economic Belt Initiative: Network and Influence Formation in Central Asia. J. Contemp. China 2018, 27, 502-518. [CrossRef]

4. Kundu, T.; Sheu, J.-B. Analysing the effect of government policy intervention on cross-border freight transportation flows: The Belt and Road perspective. Transp. A Transp. Sci. 2019, 15, 1360-1381. [CrossRef]

5. Zhang, C.; Fu, J.; Pu, Z. A study of the petroleum trade network of countries along “The Belt and Road Initiative". J. Clean. Prod. 2019, 222, 593-605. [CrossRef]

6. Zheng, L.; Yi, L.; Liu, W. The Spatio-temporal Pattern Evolution of Northeast China's Outward Direct Investment. Sci. Geogr. Sin. 2016, 36, 1329-1337. (In Chinese)

7. Zhang, Y. The Investment Facilitation of "One Belt One Road" and Choices of China's Foreign Direct Investment-Empirical Analysis Based on Cross-Panel Data and Investment Gravity Model. J. Int. Trade 2016, 9, 165-176. (In Chinese)

8. Zhang, S. Thoughts and measures on Optimizing the Distribution of Chinese Foreign Direct Investment under the "Belt and Road" Strategy. Manag. World 2017, 4, 1-9. (In Chinese)

9. Cheng, Z.; Nan, N. China's Direct Investment Efficiency and Potential Evaluation for the Countries along "Belt and Road". Commer. Res. 2017, 8, 64-73. (In Chinese)

10. Kang, L.L.; Peng, F.; Zhu, Y.; Pan, A. Harmony in Diversity: Can the One Belt One Road Initiative Promote China's Outward Foreign Direct Investment? Sustainability 2018, 10, 3264. [CrossRef]

11. Zheng, L.; Liu, Z. Spatial pattern of Chinese outward direct investment in the Belt and Road Initiative area. Prog. Geogr. 2015, 34, 563-570. (In Chinese)

12. Liu, H.; Jiang, J.; Zhang, L.; Chen, X. OFDI agglomeration and Chinese firm location decisions under the “Belt and Road" initiative. Sustainability 2018, 10, 4060. [CrossRef]

13. Fan, Z.; Zhang, R.; Liu, X.; Pan, L. China's outward FDI efficiency along the Belt and Road: An application of stochastic frontier gravity model. China Agric. Econ. Rev. 2016, 8, 455-479. [CrossRef]

14. Shi, J.; Li, H.; Guan, J.; Sun, X.; Guan, Q.; Liu, X. Evolutionary features of global embodied energy flow between sectors: A complex network approach. Energy 2017, 140, 395-405. [CrossRef]

15. Hao, X.; An, H.; Qi, H.; Gao, X. Evolution of the exergy flow network embodied in the global fossil energy trade: Based on complex network. Appl. Energy 2016, 162, 1515-1522. [CrossRef]

16. Fagiolo, G.; Reyes, J.; Schiavo, S. The evolution of the world trade web: A weighted-network analysis. J. Evol. Econ. 2010, 20, 479-514. [CrossRef]

17. De Masi, G.; Giovannetti, G.; Ricchiuti, G. Network analysis to detect common strategies in Italian foreign direct investment. Phys. A Stat. Mech. Appl. 2013, 392, 1202-1214. [CrossRef]

18. Li, H.; An, H.; Fang, W.; Wang, Y.; Zhong, W.; Yan, L. Global energy investment structure from the energy stock market perspective based on a Heterogeneous Complex Network Model. Appl. Energy 2017, 194, 648-657. [CrossRef]

19. Gao, X.Y.; Huang, S.P.; Sun, X.Q.; Hao, X.Q.; An, F. Modelling cointegration and Granger causality network to detect long-term equilibrium and diffusion paths in the financial system. R. Soc. Open Sci. 2018, 5, 172092. [CrossRef]

20. Gligor, M.; Ausloos, M. Clusters in weighted macroeconomic networks: The EU case. Introducing the overlapping index of GDP/capita fluctuation correlations. Eur. Phys. J. B 2008, 63, 533-539. [CrossRef]

21. Ausloos, M.; Gligor, M. Cluster expansion method for evolving weighted networks having vector-like nodes. Acta Phys. Pol. A 2008, 114, 491-499. [CrossRef]

22. Newman, M.E.; Barabási AL, E.; Watts, D.J. The Structure and Dynamics of Networks; Princeton University Press: Princeton, NJ, USA, 2011.

23. Wang, X.; Li, X.; Chen, G. Complex Network Theory and Its Application; Tsinghua University Press: Beijing, China, 2006. (In Chinese)

24. Saramaki, J.; Kivela, M.; Onnela, J.P.; Kaski, K.; Kertesz, J. Generalizations of the clustering coefficient to weighted complex networks. Phys. Rev. E 2007, 75, 027105. [CrossRef] [PubMed]

25. Onnela, J.P.; Saramaki, J.; Kertesz, J.; Kaski, K. Intensity and coherence of motifs in weighted complex networks. Phys. Rev. E 2005, 71, 065103. [CrossRef] [PubMed]

26. Fagiolo, G. Clustering in complex directed networks. Phys. Rev. E 2007, 76, 026107. [CrossRef]

27. Freeman, L.C. Centrality in social networks conceptual clarification. Soc. Netw. 1978, 1, 215-239. [CrossRef] 
28. Barabasi, A.L.; Albert, R. Emergence of scaling in random networks. Science 1999, 286, 509-512. [CrossRef] [PubMed]

29. Liu, W. Scientific understanding of the Belt and Road Initiative of China and related research themes. Prog. Geogr. 2015, 34, 538-544. (In Chinese)

30. Zou, J.; Liu, W. Trade Network of China and Countries Along “Belt and Road Initiative" Areas from 2001 to 2013. Sci. Geogr. Sin. 2016, 36, 1629-1636.

31. Yang, W.; Du, D.; Ma, Y.; Jiao, M. Network structure and proximity of the trade network in the Belt and Road region. Geogr. Res. 2018, 37, 2218-2235.

32. Duan, W.; Liu, B.; Ji, J. Topological structure evolution of world trade network. Syst. Eng. Theory Pract. 2008, 28, 71-75. (In Chinese)

33. Krackhardt, D. Predicting with networks: Nonparametric multiple regression analysis of dyadic data. Soc. Netw. 1988, 10, 359-381. [CrossRef]

34. Liu, J. QAP: A Unique Method of Measuring “Relationships" in Relational Data. Society 2007, $27,164$. (In Chinese)

35. Xu, H.; Cheng, L. The QAP weighted network analysis method and its application in international services trade. Phys. A Stat. Mech. Appl. 2016, 448, 91-101. [CrossRef]

36. Wang, F.; Gao, M.N.; Liu, J.; Fan, W.N. The Spatial Network Structure of China's Regional Carbon Emissions and Its Network Effect. Energies 2018, 11, 2706. [CrossRef]

37. Chong, Z.; Qin, C. The Trade Network Structure of "One Belt One Road" and its Influence Factors: A study Based on Analytic Network Process. Int. Econ. Trade Res. 2017, 33, 16-28. (In Chinese)

38. Krackardt, D. QAP partialling as a test of spuriousness. Soc. Netw. 1987, 9, 171-186. [CrossRef]

39. Lee, T. Network comparison of socialization, learning and collaboration in the C40 cities climate group. J. Environ. Policy Plan. 2019, 21, 104-115. [CrossRef]

40. Ramasamy, B.; Yeung, M.; Laforet, S. China's outward foreign direct investment: Location choice and firm ownership. J. World Bus. 2012, 47, 17-25. [CrossRef]

41. Buckley, P.J.; Clegg, L.J.; Cross, A.R.; Liu, X.; Voss, H.; Zheng, P. The determinants of Chinese outward foreign direct investment. J. Int. Bus. Stud. 2007, 38, 499-518. [CrossRef]

42. Dunning, J.H. Trade, Location of Economic Activity and the Multinational Enterprise: Some Empirical Evidence; University of Reading, Department of Economics: Reading, UK, 1977.

43. Dunning, J.H. Multinational Enterprises and the Global Economy; Addison-Wesley: Wokingham, UK, 1993.

44. Tinbergen, J.J. Shaping the World Economy; Suggestions for An International Economic Policy; Twentieth Century Fund: New York, NY, USA, 1962.

45. Navaretti, G.B.; Venables, A.J.; Barry, F. Multinational Firms in the World Economy; Princeton University Press: Princeton, NJ, USA, 2006.

46. Kalirajan, K. Regional cooperation and bilateral trade flows: An empirical measurement of resistance. Int. Trade J. 2007, 21, 85-107. [CrossRef]

47. Yang, J.H.; Wang, W.; Wang, K.L.; Yeh, C.Y. Capital intensity, natural resources, and institutional risk preferences In Chinese Outward Foreign Direct Investment. Int. Rev. Econ. Financ. 2018, 55, 259-272. [CrossRef]

48. Chakrabarti, A. The determinants of foreign direct investments: Sensitivity analyses of cross-country regressions. KYKLOS 2001, 54, 89-114. [CrossRef]

49. Thomas, D.E.; Eden, L.; Hitt, M.A.; Miller, S.R. Experience of Emerging Market Firms: The Role of Cognitive Bias in Developed Market Entry and Survival. Manag. Int. Rev. 2007, 47, 845-867. [CrossRef]

50. Mundell, R.A. International trade and factor mobility. Am. Econ. Rev. 1957, 47, 321-335.

51. Anyanwu, J.C. Why Does Foreign Direct Investment Go Where It Goes?: New Evidence From African Countries. Ann. Econ. Financ. 2012, 13, 425-462.

52. Aleksynska, M.; Havrylchyk, O. FDI from the south: The role of institutional distance and natural resources. Eur. J. Political Econ. 2013, 29, 38-53. [CrossRef]

53. Wang, Y.; Du, J.; Wang, K. The Determinants of Location Choices of China's ODI: Institutions, Taxations, Resources. Econ. Res. J. 2014, 126-142.

54. Benassy-Quere, A.; Coupet, M.; Mayer, T. Institutional determinants of foreign direct investment. World Econ. 2007, 30, 764-782. [CrossRef] 
55. Xu, T. Economic freedom and bilateral direct investment. Econ. Model. 2019, 78, 172-179. [CrossRef]

56. Cheng, L.K.; Kwan, Y.K. What are the determinants of the location of foreign direct investment? The Chinese experience. J. Int. Econ. 2000, 51, 379-400. [CrossRef]

57. Dunning, J.H. Trade, Location of Economic Activity and the MNE: A Search for an Eclectic Approach; The International Allocation of Economic Activity; Springer: Berlin/Heidelberg, Germany, 1977; pp. 395-418.

(C) 2019 by the authors. Licensee MDPI, Basel, Switzerland. This article is an open access article distributed under the terms and conditions of the Creative Commons Attribution (CC BY) license (http://creativecommons.org/licenses/by/4.0/). 